\title{
L-Arginine: A Unique Amino Acid for Improving Depressed Wound Immune Function following Hemorrhage
}

\author{
Martin K. Angele ${ }^{b}$ Stefan M. Nitsch ${ }^{a}$ Rudolf A. Hatz ${ }^{a}$ Peter Angele $^{b}$ \\ Thomas Hernandez-Richter $^{a}$ Mathias W. Wichmann ${ }^{a}$ Irshad H. Chaudry ${ }^{c}$ \\ Friedrich W. Schildberg ${ }^{\text {a }}$ \\ aDepartment of Surgery, Klinikum Grosshadern, Ludwig Maximilians University, Munich, \\ ${ }^{b}$ Department of Surgery, University of Regensburg, Germany; ' Department of Surgery, \\ University of Alabama at Birmingham, Ala., USA
}

\section{Key Words}

Hemorrhagic shock · Immune depression - Wound exudate cells . Wound infection - Organ blood flow

\begin{abstract}
Objective: To determine whether L-arginine has any salutary effects on wound immune cell function following trauma-hemorrhage. Background: Depressed wound immune function contributes to an increased incidence of wound infections following hemorrhage. Although administration of $L$-arginine has been shown to restore depressed cell-mediated immune responses following hemorrhage potentially by maintaining organ blood flow, it remains unknown whether $L$-arginine has any salutary effects on the depressed local immune response at the wound site. Methods: Male mice were subjected to a midline laparotomy and polyvinyl sponges were implanted subcutaneously in the abdominal wound prior to hemorrhage (35 $\pm 5 \mathrm{~mm} \mathrm{Hg}$ for $90 \mathrm{~min}$ and resuscitation) or sham operation. During resuscitation mice received $300 \mathrm{mg} / \mathrm{kg}$ body weight $L$-arginine or saline (vehi-
\end{abstract}

This investigation was supported by a grant from the Ludwig Maximilians University, Munich, Germany.

\section{KARGER}

Fax + 41613061234

E-Mail karger@karger.ch

www. karger.com
(C) 2002 S. Karger AG, Basel

0014-312X/02/0342-0053\$18.50/0

Accessible online at:

www. karger.com/journals/esr cle). Sponges were harvested $24 \mathrm{~h}$ thereafter, wound fluid collected and wound immune cells cultured for $24 \mathrm{~h}$ in the presence of LPS. Pro- (IL-1 $\beta$, IL-6) and anti-inflammatory (IL-10) cytokines were determined in the supernatants and the wound fluid. In addition, wounds were stained for IL-6 immunohistochemically. In a separate set of animals, skin and muscle blood flow was determined by microspheres. Results: The capacity of wound immune cells to release IL- $1 \beta$ and IL- 6 in vitro was significantly depressed in hemorrhaged mice receiving vehicle. Administration of $L$-arginine, however, improved wound immune cell function. In contrast, in vivo the increased IL- 6 release at the wound site was decreased in $L$-arginine-treated mice following hemorrhage. Moreover, IL-10 levels were significantly increased in the wound fluid in hemorrhaged animals receiving $L$-arginine compared to vehicle-treated mice. In addition, the depressed skin and muscle blood flow after hemorrhage was restored by L-arginine. Conclusions: Thus, L-arginine might improve local wound cell function by decreasing the inflammatory response at the wound site. Since $L$-arginine protected wound immune cell function this amino acid might represent a novel and useful adjunct to fluid resuscitation for decreasing wound complications following hemorrhage.

Copyright $\odot 2002$ S. Karger AG, Base

Dr. Martin K. Angele

Department of Surgery, Klinikum Grosshadern, Ludwig Maximilians University

Marchioninistrasse 15

D-81377 Munich (Germany)

Tel. +49 897095 1, Fax +49 897095 5674, E-Mail mangele@aol.com 


\section{Introduction}

Several studies indicate that trauma and hemorrhagic shock lead to profound alterations of both immune responses and organ function [1]. This depression of immune responses has been shown to be associated with an increased morbidity and mortality from subsequent sepsis $[2,3]$. Moreover, endothelial cell dysfunction occurs early after the onset of hemorrhagic shock and is manifested by reduced release of endothelium-derived NO [4]. Vascular endothelium cell-derived NO is responsible for vasorelaxation [5], for inhibiting platelet aggregation [6], and neutrophil infiltration [7]. The reduced release of endothelium-derived NO following trauma-hemorrhage is most likely due to the decreased activity of endothelial constitutive NO synthase (cNOS) [8]. Endothelial cell dysfunction appears to contribute to further depression of organ function and immune responses following trauma-hemorrhage [4]. Recent studies indicate that administration of $L$-arginine, the substrate for cNOS, during resuscitation following trauma-hemorrhage maintained organ blood flow, decreased hepatic injury and restored the depressed cell-mediated immune responses [9-12].

Similarly, markedly depressed wound immune cell function has been shown following trauma and hemorrhagic shock. These changes in wound immune cell function persist for up to 3 days after resuscitation [13] and result in an increased rate of wound infections. Since salutary effects of $L$-arginine on organ blood flow and systemic cell-mediated immune responses have been demonstrated following trauma-hemorrhage we hypothesized that administration of $L$-arginine might also maintain blood flow to the wound thereby improving the depressed local wound immune cell function. Therefore, the aim of our study was to determine whether or not infusion of $L$ arginine during resuscitation following trauma and hemorrhage has any beneficial effects on the depressed wound immune cell function following trauma-hemorrhage.

\section{Material and Methods}

\section{Animals}

Inbred male $\mathrm{C} 3 \mathrm{H} / \mathrm{HeN}$ mice (Charles River Laboratories, Germany), 7 weeks of age (24-27 g BW) were used in this study. All procedures were carried out in accordance with the guidelines set forth in the Animal Welfare Act and the Guide for the Care and Use of Laboratory Animals by the Regierung von Oberbayern and the Ludwig Maximilians University.

\section{Experimental Groups}

Male mice were randomized into three groups $(n=6-8$ per group): The mice in group 1 underwent trauma alone (sham animals), while the mice in groups 2 and 3 were subjected to the traumahemorrhage procedure (hemorrhage). Group 2 received vehicle whereas group 3 was treated with $L$-arginine.

\section{Trauma Procedure and Sponge Implantation}

Mice were lightly anesthetized with methoxyflurane (Metofane, Pitman-Moore, Mundelein, Ill., USA), restrained in a supine position, and the skin was disinfected using $75 \%$ ethanol. A $2.5-\mathrm{cm}$ midline laparotomy (i.e. trauma induced) was performed and the muscular layer was then closed aseptically using 6-0 Ethilon sutures (Ethicon, Inc., Somerville, N.J., USA). Following this polyvinyl sponges $(0.5 \mathrm{~cm}$ in diameter) (M-Pact, Eudora, USA) were aseptically implanted subcutaneously ( 3 per animal) next to the incision site avoiding contamination or infection of the wound site. The skin incision was then closed using 4.0 sutures.

\section{Hemorrhage Procedure}

Following the midline laparotomy and sponge implantation, both femoral arteries were aseptically cannulated with polyethylene 10 tubing (Clay-Adams, Parsippany, N.J., USA) using a minimal dissection technique. Blood pressure was constantly monitored by attaching one of the catheters to a blood pressure analyzer (Digi-Med ${ }^{\mathrm{TM}}$, Louisville, Ky., USA). Upon awakening, the animals were bled rapidly through the other catheter to a mean arterial blood pressure (BP) of $35 \pm 5 \mathrm{~mm} \mathrm{Hg}$ (BP prehemorrhage was $95 \pm 5 \mathrm{~mm} \mathrm{Hg}$ ), which was maintained for $90 \mathrm{~min}$. At the end of that period, the animals were resuscitated intraarterially with lactated Ringer's solution (4 times the shed blood volume over $30 \mathrm{~min}$ ) to provide adequate fluid resuscitation. Lidocaine was applied to the groin incision sites, the catheters were removed, the vessels ligated and the groin incisions closed. Sham-operated animals underwent the same groin dissection, which included ligation of both femoral arteries; however, neither hemorrhage nor fluid resuscitation were carried out. No mortality was observed in this trauma-hemorrhage model.

\section{L-Arginine Administration}

At the beginning of resuscitation in hemorrhaged animals, either saline (vehicle) or $L$-arginine ( $300 \mathrm{mg} / \mathrm{kg}$ body weight in $1.0 \mathrm{ml}$ normal saline) (Sigma Chemical Co., St. Louis, Mo., USA) was infused via the femoral catheter over a period of $15 \mathrm{~min}$ at a constant rate. The dose of $300 \mathrm{mg} / \mathrm{kg}$ body weight $L$-arginine was chosen in accordance with our previous studies which demonstrated salutary effects on the depressed organ blood flow and the depressed cell-mediated immune responses following trauma-hemorrhage with $L$-arginine administration $[10,11]$.

\section{Preparation of Wound Exudate Cells from the Sponges}

The animals were sacrificed by methoxyflurane overdose on the first postoperative day after hemorrhage and resuscitation or sham operation. The sponges were dissected free from the surrounding connective tissue using sterile surgical methods. Wound exudate from the sponges was harvested as previously described [14, 15]. In brief, the sponges from each animal were combined and centrifuged at $300 \mathrm{~g}$ for $15 \mathrm{~min}$ at $4{ }^{\circ} \mathrm{C}$ for isolation of the wound fluid. Following this the sponges were transferred into a plastic bag with icecold phosphate-buffered saline. The sponges were repeatedly compressed and the resultant cell suspension was centrifuged at $300 \mathrm{~g}$ for
Angele/Nitsch/Hatz/Angele/ Hernandez-Richter/Wichmann/Chaudry/ Schildberg 
$15 \mathrm{~min}$ at $4^{\circ} \mathrm{C}$. The cell pellet of wound exudate cells was diluted to $1.5 \times 10^{6}$ cells $/ \mathrm{ml}$ in RPMI 1640 medium containing $10 \%$ fetal calf serum and gentamicin. One milliliter of this cell suspension was cultured on a 24 -well plate for $24 \mathrm{~h}$ at $37^{\circ} \mathrm{C}, 5 \% \mathrm{CO}_{2}$ and $90 \%$ humidity in the presence of $10 \mu \mathrm{g} / \mathrm{ml}$ of lipopolysaccharide A (LPS). After incubation, the cell suspension was centrifuged at $300 \mathrm{~g}$ for $15 \mathrm{~min}$ at $4^{\circ} \mathrm{C}$, the supernatants harvested and stored at $-80^{\circ} \mathrm{C}$ until assayed for IL-1 $\beta$, IL-6, and IL-10 levels.

Assessment of Interleukin-1 $\beta$, Interleukin-6, and Interleukin-10

Interleukin-1 $\beta$, Interleukin-6, and IL-10 levels in wound cell supernatants and wound fluid were determined using the SandwichEnzyme Linked Immunoassay (ELISA) technique as described previously [16]

\section{Immunhistochemistry}

Sections of the wound site were fixed in $4 \%$ paraformaldehyd. Paraffine blocks of specimens were cut at $1-2 \mu \mathrm{m}$. The specimens were stained using avidine-biotine-complex. In brief, the sections were incubated with primary polyclonal goat IL-6 anti-mouse antibody (R\&D Systems) at dilution of 1:200 for $1 \mathrm{~h}$ at room temperature. Following this, a biotinylated anti-goat antibody (Dianova, Hamburg, Germany) was added at a dilution of 1:4,000 for $30 \mathrm{~min}$ at room temperature. Then, the sections were incubated at room temperature for $30 \mathrm{~min}$ with a streptavidine-peroxidase-conjugated antibody at a dilution of 1:200. 3'amino-9'ethyl carbazole (Sigma) was added for $8 \mathrm{~min}$ to initiate color development. The slides were evaluated double-blinded by two separate investigators.

\section{Determination of Skin and Muscle Blood Flow}

In a separate set of animals rats were used to measure the effect of $L$-arginine on the depressed skin and muscle blood flow following trauma-hemorrhage. Those experiments were performed in rats since the microspheres method has been established in rats in our hands previously [11]. Moreover, similar changes in organ blood flow have been demonstrated in mice and rats following severe blood loss [17] The non-heparinized model of trauma-hemorrhage and crystalloid resuscitation in the rat used in the present study has been previously described in detail by us [11]. Briefly, male Sprague-Dawley rats (Charles River Laboratories, Germany) (260-325 g) were anesthetized with methoxyflurane (Pitman-Moore, Mundelein, Ill., USA) and a $5-\mathrm{cm}$ ventral midline laparotomy was performed to induce soft-tissue trauma prior to hemorrhage. The abdominal incision was then closed in two layers following which both femoral arteries and one femoral vein were cannulated with polyethylene (PE) 50 tubing (Clay-Adams, Parsippany, N.J., USA). Immediately after recovery from anesthesia, the animals were bled to a mean arterial pressure (MAP) of $40 \mathrm{~mm} \mathrm{Hg}$ within $10 \mathrm{~min}$. This pressure $(40 \mathrm{~mm} \mathrm{Hg}$ ) was maintained until $40 \%$ of the shed blood volume was returned in the form of Ringer's lactate (RL) At that time $(\sim 1.5 \mathrm{~h}$ from the onset of hemorrhage), the rats were resuscitated intravenously with 4 times $(\sim 45 \mathrm{ml} / \mathrm{rat}$ ) the volume of maximal bleedout with RL over $60 \mathrm{~min}$. At the beginning of resuscitation $L$-arginine $(300 \mathrm{mg} / \mathrm{kg} \mathrm{BW}$ in $1.0 \mathrm{ml}$ normal saline) or normal saline was infused via the femoral venous catheter over a period of $15 \mathrm{~min}$. Skin and muscle blood flow was determined $4 \mathrm{~h}$ after the completion of fluid resuscitation or sham operation using the microspheres method as previously described [18]. In brief, a PE-10 tubing was placed via the carotid artery in the left ventricle. Strontium-85-labeled microspheres $(13.8 \pm 0.6 \mu \mathrm{m}$ diameter; specific activity, $12.3 \mathrm{mCi} / \mathrm{g}$ ) were suspended in $10 \%$ dex-
Table 1. Total number of wound immune cells and percentage of $M \Phi$ and PMN in wound cells harvested from the sponges $24 \mathrm{~h}$ following hemorrhage or sham operation

\begin{tabular}{lrrr}
\hline & Cells, $\times 10^{6}$ & M $\Phi, \%$ & PMN, \% \\
\hline Sham & $6.7 \pm 0.8$ & $9.9 \pm 1.0$ & $90.1 \pm 1.1$ \\
Hemorrhage vehicle & $9.7 \pm 2.5$ & $7.0 \pm 0.9$ & $93.0 \pm 0.9$ \\
Hemorrhage $L$-arginine & $10.5 \pm 1.5$ & $7.5 \pm 1.3$ & $92.5 \pm 1.3$
\end{tabular}

Total number of wound immune cells and percentage of $\mathrm{M} \Phi$ and $\mathrm{PMN}$ in the wound exudate cells harvested from sponges which had been implanted in male mice $(\mathrm{C} 3 \mathrm{H} / \mathrm{HeN})(\mathrm{n}=6 /$ group $)$. The sponges were harvested on the first postoperative day after hemorrhage or sham operation. Hemorrhaged animals were treated with saline (vehicle) or $L$-arginine at the beginning of resuscitation.

Values are presented as means \pm SEM.

tran containing $0.05 \%$ Tween- 80 surfactant to prevent aggregation. An estimated 150,000 microspheres were injected into each animal. Skin and muscle from the abdominal wall were removed, washed, weighted and the radioactivity was counted. Following this, muscle and skin blood flow was calculated. None of the animals died during the study period, and the rats were sacrificed at the end of the experiment by an overdose of methoxyflurane. There were 6-8 animals in each group at each time point.

\section{Statistical Analysis}

The results are presented as mean \pm SEM. One way ANOVA followed by the Tukey's test as a post hoc test for multiple comparisons was used to determine the significance of the differences between experimental means. Significance between the colony forming units were determined using Student's $t$ test. A $p$ value $<0.05$ was considered statistically significant.

\section{Results}

\section{The Distribution of Polymorphonuclears (PMN) and

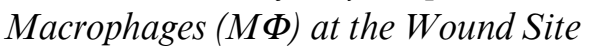

The number of wound exudate cells (table 1) as well as the percentage of MФ and PMN was similar in hemorrhaged and sham-operated animals. Moreover, administration of $L$-arginine did not affect the number of wound exudate cells or the distribution of PMN and $M \Phi$ within the wound immune cells.

\section{Proinflammatory Cytokine Release by Wound Exudate Cells}

There was a significant decrease in the LPS stimulated release of IL-1 $\beta$ (fig. 1A) in vitro by wound exudate cells following hemorrhage $(-55.3 \%$ compared to sham-oper- 


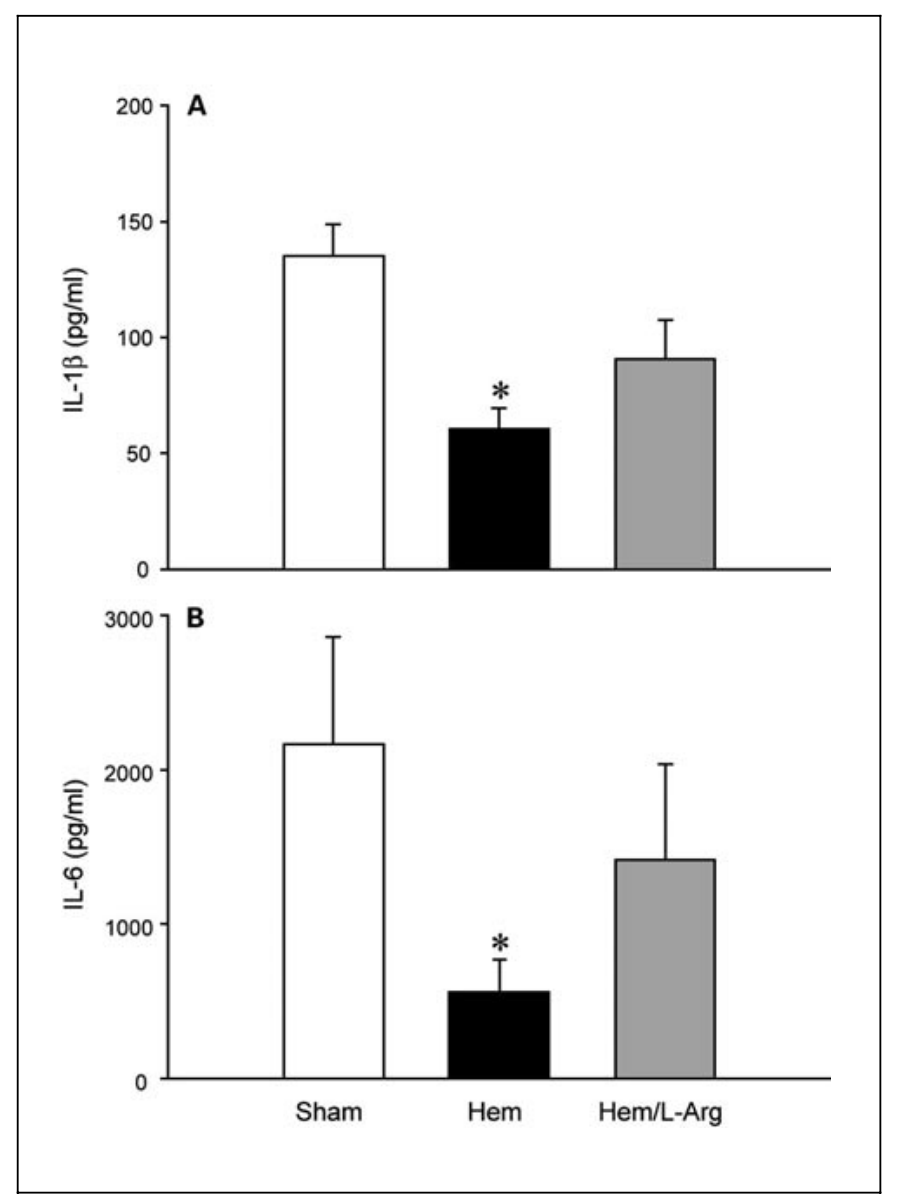

Fig. 1. Release of IL-1 $\beta$ (A) and IL-6 (B) by wound exudate cells harvested from subcutaneous sponges from male $\mathrm{C} 3 \mathrm{H} / \mathrm{HeN}$ mice ( $n=5-7 /$ group) on the first postoperative day following sham operation (Sham) or hemorrhage and resuscitation (Hem). At the beginning of resuscitation, normal saline (veh) or $300 \mathrm{mg} / \mathrm{kg}$ BW $L$-arginine ( $L$-Arg) was infused. The cells were cultured for $24 \mathrm{~h}$ in the presence of $10 \mu \mathrm{g} / \mathrm{ml}$ lipopolysaccharide A. The release of IL-1 $\beta$ and of IL-6 was determined by ELISA. Data are presented as mean \pm SEM and compared with one-way analysis of variance (ANOVA) and Tukey's test as a post-hoc test. $* p<0.05$ versus Sham.

ated animals, $\mathrm{p}<0.05)$. Administration of $L$-arginine during resuscitation, however, attenuated the depressed IL$1 \beta$ release by wound exudate cells $(+49.5 \%$ compared to hemorrhaged animals receiving vehicle).

The LPS-stimulated release of IL-6 (fig. 1B) was markedly depressed on the first postoperative day following hemorrhagic shock (-74.2\% compared to sham-operated animals, $\mathrm{p}<0.05$ ). As demonstrated in figure $1 \mathrm{~B}$, the depressed IL-6 release by wound exudate cells in vitro was restored with $L$-arginine administration $(+153.4 \%$ compared to hemorrhaged animals receiving vehicle).
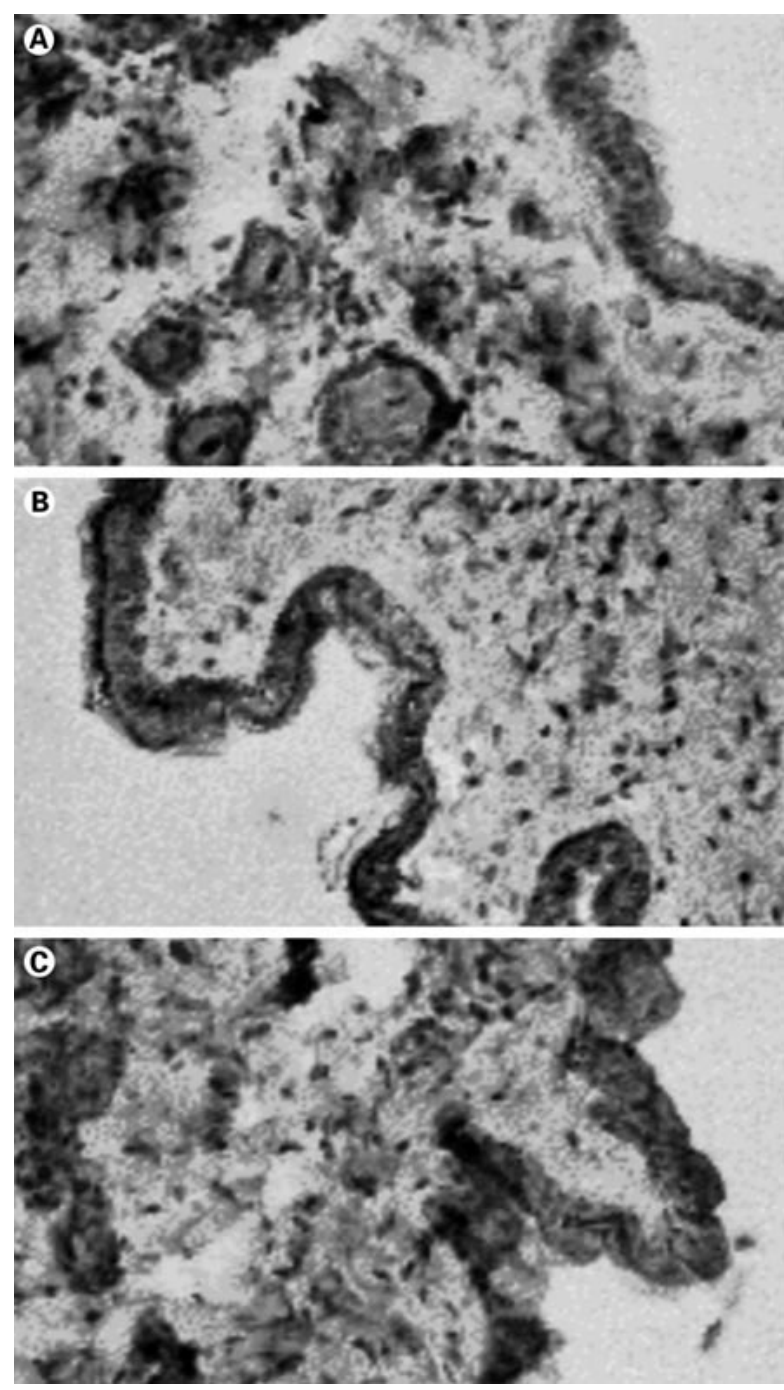

Fig. 2. Immunhistochemistry slides of the wound site on the first postoperative day following sham operation (Sham) or hemorrhage and resuscitation (Hem) stained for IL- 6 . At the beginning of resuscitation, normal saline (veh) or $300 \mathrm{mg} / \mathrm{kg} \mathrm{BW}$. $L$-arginine ( $L$-Arg) was infused. A representative slide for each study group is shown.

\section{IL-6 at the Wound Site in vivo}

Immunhistochemical sections stained for IL-6 indicate that following hemorrhage IL- 6 was increased around the wound incision site in vivo. $L$-Arginine, however, decreased IL-6 at the wound. One representative slide for each group is shown (fig. 2A-C).

\section{Proinflammatory Cytokines in the Wound Fluid}

There were no significant differences evident in the concentration of the proinflammatory cytokines IL- $1 \beta$ and IL-6 in the wound fluid among the three study groups (table 2). 


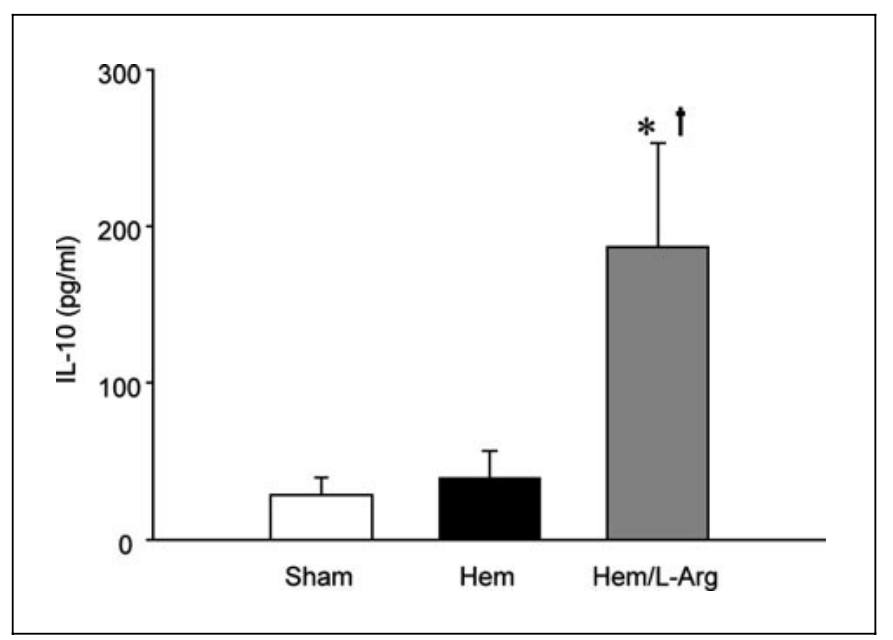

Fig. 3. IL-10 level in the wound fluid harvested from subcutaneous sponges from male $\mathrm{C} 3 \mathrm{H} / \mathrm{HeN}$ mice $(\mathrm{n}=5-7 /$ group $)$ on the first postoperative day following sham operation (Sham) or hemorrhage and resuscitation (Hem). At the beginning of resuscitation, normal saline (veh) or $300 \mathrm{mg} / \mathrm{kg} \mathrm{BW.} L$-arginine ( $L$-Arg) was infused. IL-10 was determined by ELISA. Data are presented as mean \pm SEM and compared with one-way analysis of variance (ANOVA) and Tukey's test as a post-hoc test. ${ }^{*} \mathrm{p}<0.05$ versus Sham,${ }^{\dagger} \mathrm{p}<0.05$ versus Hem.

Table 2. Concentration of IL- $1 \beta$ and IL-6 in the wound fluid on the first postoperative day following hemorrhage or sham operation

\begin{tabular}{lccc}
\hline & Sham & $\begin{array}{l}\text { Hemorrhage } \\
\text { vehicle }\end{array}$ & $\begin{array}{l}\text { Hemorrhage } \\
\text {-arginine }\end{array}$ \\
\hline $\mathrm{IL}-1 \beta, \mathrm{pg} / \mathrm{ml}$ & $1,577 \pm 117$ & $1,053 \pm 188$ & $1,529 \pm 237$ \\
$\mathrm{IL}-6, \mathrm{pg} / \mathrm{ml}$ & $22.8 \pm 7.1$ & $15.8 \pm 3.7$ & $27.6 \pm 14.6$
\end{tabular}

Concentration of IL-1 $\beta$ and IL-6 in the wound fluid harvested from animals on the first postoperative day after hemorrhage or sham operation. Hemorrhaged animals were treated with saline (vehicle) or $L$-arginine at the beginning of resuscitation. IL-1 $\beta$ and IL-6 were measured in the wound fluid by ELISA.

Values are presented as means \pm SEM.

\section{Antiinflammatory Cytokines in the Wound Fluid}

Similar levels of IL-10 were detectable in the wound fluid of sham animals and hemorrhaged animals receiving vehicle (fig. 3). In contrast to the proinflammatory cytokine levels, administration of $L$-arginine, significantly increased IL-10 levels in the wound fluid following trauma-hemorrhage ( $+382 \%$ compared to hemorrhaged animals receiving vehicle).

L-Arginine Improves Wound Immune

Function

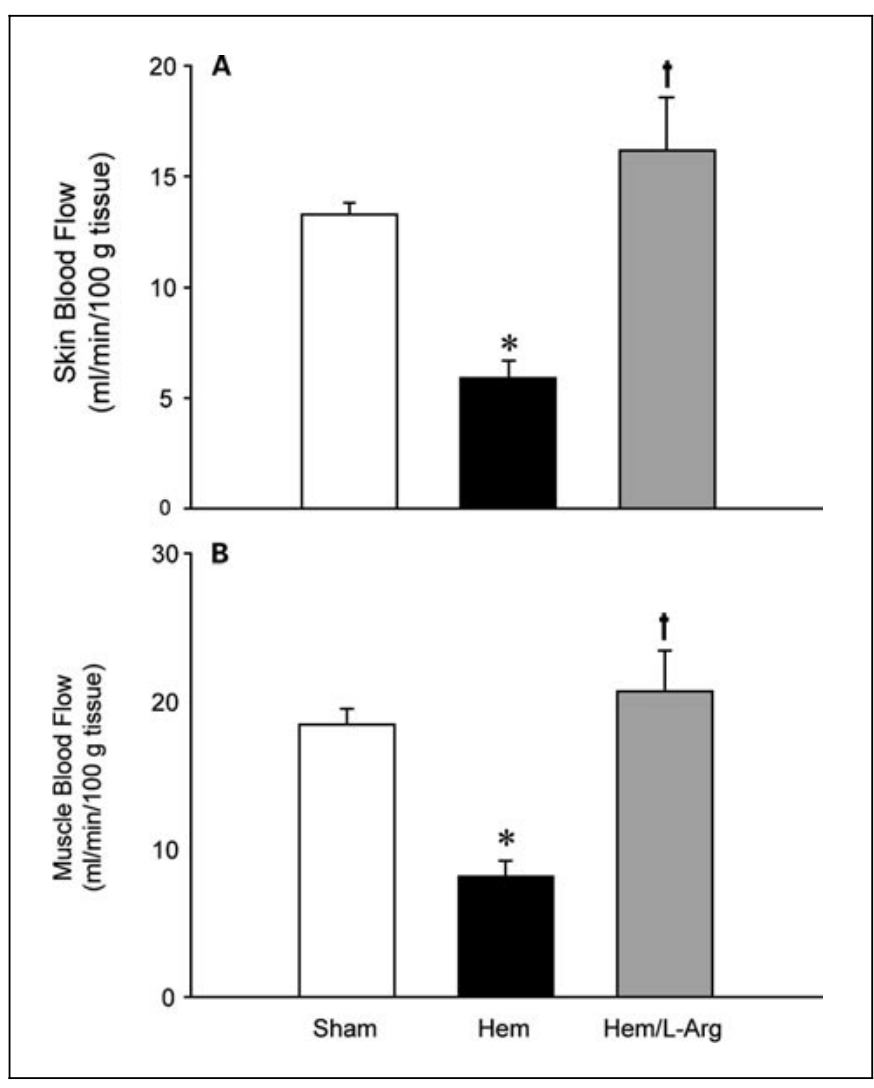

Fig. 4. Effect of $L$-arginine administration on skin (A) and muscle (B) blood flow at $4 \mathrm{~h}$ following sham operation (Sham) or hemorrhage and resuscitation (Hem). At the beginning of resuscitation, normal saline (veh) or $300 \mathrm{mg} / \mathrm{kg} \mathrm{BW} L$-arginine ( $L$-Arg) was infused. Data are presented as mean \pm SEM and compared with one-way analysis of variance (ANOVA) and Tukey's test as a post-hoc test. * $\mathrm{p}<0.05$ versus Sham, ${ }^{\dagger} \mathrm{p}<0.05$ versus Hem.

\section{Effects of L-Arginine on Skin and Muscle Blood Flow}

Skin (fig. 4A) and muscle (fig. 4B) blood flow was significantly decreased in hemorrhaged animals receiving vehicle at $4 \mathrm{~h}$ after resuscitation $(-55.6$ and $-55.7 \%$ compared to sham-operated animals, respectively, $\mathrm{p}<0.05$ ). $L$-arginine administration during crystalloid resuscitation in trauma-hemorrhaged animals restored organ blood flow in the skin and muscle $(+175$ and $+152 \%$ compared to sham-operated animals, respectively, $\mathrm{p}<0.05$ ).

\section{Discussion}

Wound infections remain the leading complication following severe trauma [19] accounting for approximately a quarter of the total number of nosocomial infections [20].

Eur Surg Res 2002;34:53-60 
Furthermore, surgical wound infections continue to consume a considerable portion of health care finances [21]. In this respect, studies by Olson et al. demonstrate that a reduction of the overall wound infection rate from 4.2 to $2.5 \%$ at one medical center saved approximately USD 3 million on hospital room costs during a 10-year period [22]. In addition, wound infections are a potential source for increasing morbidity and mortality in surgical patients as a result of subsequent tissue inflammation and infection, the latter being especially common in the presence of compromised immune functions seen in the critically ill patient [23-25]. In experimental studies, depressed wound immune cell function has been shown following hemorrhagic shock which persists for up to three days [13]. Moreover, the depressed wound immune cell function following severe blood loss has been found to be associated with an increased susceptibility of hemorrhaged animals to wound infection [26]. Antibiotics failed to decrease the rate of wound infection in hemorrhaged animals [26, 27] further supporting the notion that alterations in host defense mechanisms at the wound site contribute to wound infections. Since administration of $L$ arginine following trauma-hemorrhage restored the depressed splenic and peritoneal macrophage function as well as splenocyte responses $[10,12]$ it was the aim of the present study to determine whether $L$-arginine also exhibits any salutary effects on the depressed wound immune cell function under such conditions.

To study whether $L$-arginine attenuates immune cell dysfunction at the wound site, polyvinyl sponges were implanted in the laparotomy wound and wound exudate cells were harvested on the first postoperative day. Sponges were utilized in the present study since wound exudate cells cannot be harvested directly from the wound site. Furthermore, implantation of sponges is a commonly used and well described experimental method for obtaining wound exudate cells [13-15, 28]. It should be pointed out that the wound exudate cells assessed in the present study represent an unpurified (mixed) cellular sample composed of primarily PMN and MФ. This was done in an attempt to simulate the in vivo setting of wound exudate cells and their immune response to a second stimulus in vitro.

The results of the present study indicate that wound immune cell cytokine release in response to LPS was markedly depressed in vehicle-treated animals following trauma-hemorrhage on the first postoperative day. Administration of $L$-arginine at the beginning of resuscitation, however, attenuated the depressed wound immune cell function $24 \mathrm{~h}$ following hemorrhage. Since the distri- bution of wound exudate cells was unaffected by hemorrhage or $L$-arginine administration the observed improvement in the cytokine release in $L$-arginine treated animals does not appear to be due to variations in the distribution of wound exudate cells. Wound cells were harvested on the first postoperative day since previous studies demonstrate maximal depression of wound immune cell function at this time point following shock.

Interleukin-1 $\beta$ and IL-6 were determined in the present study since both cytokines have been shown to be involved in the wound healing process in experimental wound models and in surgical patients $[14,15]$. Interleukin-1 and IL-6 stimulate leukocyte chemotaxis, T and B cell activity and PMN bactericidal activity [29-31]. A decreased capacity of wound cells to release proinflammatory cytokines following glucocorticoid treatment in mice has been reported to be associated with an increased rate of wound complications [32, 33]. In addition, the capacity of wound exudate cells to release proinflammatory cytokines in response to LPS was used as a marker to determine the responsiveness of wound exudate cells to a second stimulus following hemorrhagic shock or sham operation. Furthermore, a decreased release of proinflammatory cytokines by splenic and peritoneal $\mathrm{M} \Phi$ in response to subsequent stimulation has been demonstrated following hemorrhagic shock [1]. This hyporesponsiveness of splenic and peritoneal $\mathrm{M} \Phi$ following hemorrhage was associated with dysfunction of these cells (i.e., impaired antigen presentation and cytotoxicity) $[34,35]$. Normalization of the depressed cell-mediated immune responses by various immunomodulatory agents, i.e. flutamide [3], DHEA [36], metoclopramide [37] etc., decreased the susceptibility of hemorrhaged animals to polymicrobial sepsis. Thus, although the effect of $L$-arginine on the susceptibility of hemorrhaged animals to wound infection has not been determined our results suggest that the attenuated wound immune function might result in a decreased rate of wound infections. This hypothesis is further supported by the previous finding that the restored cytokine release of wound immune cells on the fifth postoperative day following hemorrhage results in an unaltered rate of wound infections compared to sham-operated animals [13, 26]. It remains unknown, however, whether other functional aspects of wound immune cell function, i.e. depressed phagocytic activity [13] are improved by $L$-arginine.

It should be noted that administration of $L$-arginine in sham-operated animals did not alter systemic immune responses or organ blood flow in previous studies [10-12]. Although the effect of $L$-arginine on wound immune function in sham-operated animals was not determined these
58

Eur Surg Res 2002;34:53-60
Angele/Nitsch/Hatz/Angele/

Hernandez-Richter/Wichmann/Chaudry/ Schildberg 
results support the notion that in normal animals there is an adequate amount of endogenous $L$-arginine to saturate NOS activity $[6,11]$. Administration of $L$-arginine in the early stage of resuscitation following hemorrhage, however, ameliorated the depressed local wound immune function, restored systemic cell-mediated immune responses, and maintained cardiovascular responses [11, 12]. Those findings suggest that the levels of endogenous $L$-arginine might decrease following adverse circulatory conditions, and thus administration of the exogenous substrate serves to increase or replete those stores. Whether the decreased endogenous levels of $L$-arginine following hemorrhage are due to the decreased availability of this amino acid or due to increased arginase activity remains to be determined.

The precise mechanism responsible for improving the hyporesponsiveness of wound cells following hemorrhagic shock by $L$-arginine administration seen in the present study remains unknown. Several studies suggest that hemorrhage causes a decrease in organ blood flow which results in regional hypoxia [4, 38]. Regional hypoxia appears to be an important endogenous mediator of the immunological response to injury [4]. In this regard, $L$ arginine, the substrate for nitric oxide synthase, has recently been shown to restore the depressed blood flow in various organs, i.e. liver, spleen, intestine, following trauma-hemorrhage [2]. The present study further extends those findings as evidenced by restoration of the depressed skin and muscle blood flow in $L$-arginine-treated animals following hemorrhagic shock. The increased skin and muscle blood flow in $L$-arginine-treated animals might attenuate the decreased subcutaneous wound oxygen tension thereby attenuating wound immune cell function in those animals following hemorrhage. In this respect, depressed oxygen tension at the wound site has previously been shown to increase the rate of wound infection [39]. Similarly, the resistance to infection of musculocutaneous flaps in dogs was decreased in animals housed in $12 \%$ oxygen compared to normoxic conditions [40]. In addition, IL-6 levels in the tissue around the incision were decreased in $L$-arginine-treated mice after hemorrhage. In this respect, studies by Mateo et al. [14] suggest that IL-6 is one of the major contributors to the inhibitory effects of wound fluid on fibroblast proliferation. Thus, $L$-arginine might directly or indirectly decrease the hyperinflammation at the wound. Alternatively, locally increased levels of IL-10 in the wound fluid might prevent an increased inflammatory response thereby protecting wound immune cell function in vitro. Ertel et al. [41] demonstrated an attenuated proinflammatory cytokine release following in vivo administration of IL-10 after endotoxemia. Furthermore, addition of IL-10 to the culture medium of PBMCs decreased the stressed induced proinflammatory cytokine release [42]. Those findings further support the notion that elevated IL-10 levels might decrease shock-induced immunodysfunction.

In summary, the present study demonstrates that administration of $L$-arginine during resuscitation following hemorrhagic shock attenuates the depressed wound exudate cell function in vitro and decreases the inflammatory response in vivo potentially by restoring the depressed muscle and skin blood flow. Furthermore, the antiinflammatory cytokine IL-10 which is elevated in the wound fluid of hemorrhaged animals following $L$-arginine administration might contribute to the improved wound immune cell response under such conditions. Since depressed wound immune cell function has been shown to be associated with an increased rate of wound infections our results suggest that $L$-arginine treatment might decrease the rate of wound infections following severe blood loss. Therefore, attempts to improve immune cell function at the wound site by administration of the physiological amino acid $L$-arginine might represent a helpful and useful approach for decreasing the incidence of wound infections in trauma victims. 


\section{References}

1 Chaudry IH, Ayala A: Immunological Aspects of Hemorrhage. Austin, TX: Medical Intelligence Unit; R.G. Landes Company, 1992, pp 1-132.

2 Stephan RN, Kupper TS, Geha AS, Baue AE, Chaudry IH: Hemorrhage without tissue trauma produces immunosuppression and enhances susceptibility to sepsis. Arch Surg 1987; 122:62-68.

3 Angele MK, Wichmann MW, Ayala A, Cioffi WG, Chaudry IH: Testosterone receptor blockade after hemorrhage in males: Restoration of the depressed immune functions and improved survival following subsequent sepsis. Arch Surg 1997;132:1207-1214.

4 Wang P, Ba ZF, Chaudry IH: Endothelial cell dysfunction occurs very early following trauma- hemorrhage and persists despite fluid resuscitation. Am J Physiol 1993;265:H973H979.

5 Furchgott RF: Studies on endothelium-dependent vasodilation and the endothelium-derived relaxing factor. Acta Physiol Scand 1990;139: 257-270.

6 Weyrich AS, Ma X, Lefer AM: The role of $L$ arginine in ameliorating reperfusion injury after myocardial ischemia in the cat. Circulation 1992:86:279-288.

7 McCall TB, Broughton-Smith NK, Palmer RM, Whittle BJ, Moncada S: Synthesis of nitric oxide from $L$-arginine by neutrophils: Release and interaction with superoxide anion. Biochem J 1989;261:293-296.

8 Lefer AM: Endotoxin, cytokines, and nitric oxide in shock: An editorial comment. Shock 1994;1:79-80

9 Angele MK, Fitzal F, Smail N, Knoferl MW, Schwacha MG, Ayala A, Wang P, Chaudry IH: $L$-Arginine: A unique agent for decreasing liver injury after trauma-hemorrhage. Crit Care Med 2000;28:3242-3248.

10 Angele MK, Smail N, Ayala A, Cioffi WG, Bland K, Chaudry IH: L-arginine: a unique amino acid for restoring the depressed immune functions following trauma-hemorrhage. J Trauma 1998;46:34-41.

11 Angele MK, Smail N, Wang P, Cioffi WG Bland KI, Chaudry IH: L-Arginine restores the depressed cardiac output and regional perfusion following trauma-hemorrhage. Surgery 1998;124:394-401.

12 Angele MK, Smail N, Knoferl MW, Ayala A Cioffi WG, Chaudry IH: $L$-arginine restores splenocyte functions after trauma-hemorrhage potentially by improving splenic blood flow. Am J Physiol 1999;276:C145-C151.

13 Angele MK, Knoferl MW, Schwacha MG, Ayala A, Bland KI, Cioffi WG, Josephson SL, Chaudry IH: Hemorrhage decreases macrophage inflammatory protein-2 (MIP-2) and IL6 release: A potential mechanism for increased wound infection. Ann Surg 1999;229:651661.
14 Mateo RB, Reichner JS, Albina JE: Interleukin-6 activity in wounds. Am J Physiol 1994; 266:R1840-R1844.

15 Ford HR, Hoffman RA, Wing EJ, Magee DM, McIntyre L, Simmons RL: Characterization of wound cytokines in the sponge matrix model. Arch Surg 1989;124:1422-1428.

16 Ayala A, Deol ZK, Lehman DL, Herdon CD, Chaudry IH: Polymicrobial sepsis but not low dose endotoxin infusion causes decreased splenocyte IL-2/IFN-gamma release while increasing IL- 4/IL-10 production. J Surg Res 1994;56: 579-585.

17 Wang P, Ba ZF, Burkhardt J, Chaudry IH: Trauma-hemorrhage and resuscitation in the mouse: effects on cardiac output and organ blood flow. Am J Physiol 1993;264:H1166H1173.

18 Wang P, Ba ZF, Burkhardt J, Chaudry IH: Measurement of hepatic blood flow following trauma and severe hemorrhage with different methods: Lack of restoration despite adequate crystalloid resuscitation. Am J Physiol 1992; 262:G92-G98

19 O'Keefe GE, Maier RV, Diehr P, Grossman D, Jurkovich GJ, Conrad D: The complications of trauma and their associated costs in a level I trauma center. Arch Surg 1997;132:920-924.

20 Nichols RL: Surgical wound infection. Am J Med 1991;91:54S-64S.

21 Sawyer RG, Pruett TL: Wound infections. Surg Clin North Am 1994;74:519-536.

22 Olson MM, Lee JT Jr: Continuous, 10-year wound infection surveillance. Results, advantages, and unanswered questions. Arch Surg 1990; 125:794-803.

23 Goris R, Te Boekhorst T, Nuytinck J: Multipleorgan failure: Generalized autodestructive inflammation. Arch Surg 1985;120:1109

24 Hunt TK, Knighton D, Goodson W: Wound healing in current surgical diagnosis and treatment. Crit Care Med 1988;16:86-98.

25 Baue AE: Multiple organ failure; in Baue AE (ed): Multiple Organ Failure: Patient Care and Prevention. St. Louis, Mosby Year Book, 1990, pp 421-470.

26 Livingston DH, Malangoni MA: An experimental study of susceptibility to infection after hemorrhagic shock. Surg Gynecol Obstet 1989; 168:138-142.

27 Miles AA: Nonspecific defense reactions in bacterial infections. Ann NY Acad Sci 1956; 66:356-369.

28 Angele MK, Knoferl MW, Ayala A, Albina JE, Cioffi WG, Bland KI, Chaudry IH: Increased proinflammatory cytokines at the wound site following trauma-hemorrhage: A potential mechanism for delayed wound healing. Surgery 1999;126:279-285
29 Schaffer MR, Efron PA, Thorton FJ, Klingel K, Gross SS, Barbul A: Nitric oxide, an autocrine regulator of wound fibroblast synthetic function. J Immunol 1997; 158:2375-2381.

30 Thornton FJ, Schaffer MR, Barbul A: Wound healing in sepsis and trauma. Shock 1997;8: 391-401.

31 Simms HH, D’Amico R: Studies on polymorphonuclear leukocyte bactericidal function: The role of exogenous cytokines. Shock 1997; 84-89.

32 Hubner G, Brauchle M, Smola H, Madlener M, Fassler R, Werner S: Differential regulation of pro-inflammatory cytokines during wound healing in normal and glucocorticoid-treated mice. Cytokine 1996;8:548-556.

33 Fahey TJ, Sadaty A, Jones WG, Barber A, Shires GT: Diabetes impairs the late inflammatroy response to wound healing. J Surg Res 1991;50:308-313.

34 Ayala A, Ertel W, Chaudry IH: Trauma-induced suppression of antigen presentation and expression of major histocompatibility class II antigen complex in leukocytes. Shock 1996;5: 79-90.

35 Ayala A, Perrin MM, Wang P, Ertel W, Chaudry IH: Hemorrhage induces enhanced Kupffer cell cytotoxicity while decreasing peritoneal or splenic macrophage capacity: Involvement of cell-associated TNF and reactive nitrogen. $\mathrm{J}$ Immunol 1991;147:4147-4154.

36 Angele MK, Catania RA, Ayala A, Cioffi WG, Bland K, Chaudry IH: Dehydroepiandrosterone (DHEA): An inexpensive steroid hormone which decreases the mortality from sepsis. Arch Surg 1998;133:1281-1288.

37 Zellweger R, Zhu X-H, Wichmann MW, Ayala A, DeMaso CM, Chaudry IH: Prolactin administration following hemorrhagic shock improves macrophage cytokine release capacity and decreases mortality from subsequent sepsis. J Immunol 1996;157:5748-5754.

38 Chaudry IH, Ayala A: Immune consequences of hypovolemic shock and resuscitation. Curr Opin Anaesthesiol 1993;6:385-392.

39 Fry DE: Diagnosis and epidemiology of multiple organ failure; in Deitch EA (ed): Multiple Organ Failure - Pathophysiology and Basic Concepts of Therapy. New York, Thieme, 1990, pp 13-25.

40 Jonsson K, Hunt TK, Mathes SJ: Oxygen as an isolated variable influences resistance to infection. Ann Surg 1988;208:783-787.

41 Ertel W, Keel M, Steckholzer U, Ungethum U, Trentz O: Interleukin-10 attenuates the release of proinflammatory cytokines but depresses splenocyte functions in murine endotoxemia. Arch Surg 1996;131:51-56.

42 Wang P, Wu P, Siegel MI, Egan RW, Billah MM: IL-10 inhibits transcription of cytokine genes in human peripheral blood mononuclear cells. J Immunol 1994;153:811-816.
Angele/Nitsch/Hatz/Angele/ Hernandez-Richter/Wichmann/Chaudry/ Schildberg 